\title{
MÁLFREGNIR
}

\section{Steinpór Steingrímsson}

\author{
Risamálheildin
}

\section{Inngangur}

Í maí 2018 var ný textamálheild, Risamálheildin, opnuð á vefnum málheildir.árnastofnun.is. Risamálheildin er leitarbær í leitarvél sem er sérsmíðuð fyrir málheildir og aðlöguð að íslenskum textum en einnig er hægt að sækja alla textana sem í henni eru, markaða og lemmaða, til nota við próun á máltæknibúnaði eða í rannsóknir. Fyrsta útgáfa málheildarinnar inniheldur yfir 1200 milljón lesmálsorð í textum úr ýmsum áttum. Stefnt er að pví að gefa út nýja útgáfu málheildarinnar árlega, par sem fleiri textum hefur verið bætt við og hún mörkuð og lemmuð með nýjustu aðferðum.

\section{Markmið}

Skömmu eftir að vinnu við Markaða íslenska málheild (Sigrún Helgadóttir o.fl. 2012) lauk var ljóst að pörf væri á miklu stærri textagrunni ef ætlunin væri að nýta nýjar gagnafrekar aðferðir í máltækni til hlýtar. Í pví ljósi var lögð inn umsókn um gerð gríðarstórrar málheildar í Innviðasjóð vorið 2015. Aðalumsækjandi var Eiríkur Rögnvaldsson en með honum Sigrún Helgadóttir, Steinpór Steingrímsson, Jón Guðnason, Hrafn Loftsson og Pórhallur Eypórsson. Verkefnið var að koma upp textagrunni með gífurlegu magni texta, allt að 500 milljón orð-

Orð og tunga 21 (2019), 159-168. (c) Steinpór Steingrímsson. CC BY-NC-SA 4.0. 
um. Málheildin skyldi verða öllum aðgengileg í gegnum veflæga málheildarleitarvél auk pess sem hægt yrði að hala henni niður ásamt lýsigögnum. Eftir reynslu af smíði Markaðrar íslenskrar málheildar var ákveðið að við gerð pessarar nýju málheildar yrði fyrst og fremst aflað texta sem til væru á stafrænu sniði og auðvelt væri að vinna með. Рað flýtir fyrir allri vinnu og gerir okkur kleift að einbeita okkur að söfnun á miklu magni texta, frekar en að verja miklum tíma í að koma textum á aðgengilegt stafrænt form. Pá var ákveðið að málheildin yrði gefin út með eins opnum leyfum og nokkur kostur væri, til að greiða fyrir notkun og allri vinnu með málheildina.

Auk pess að nýtast í máltækni gæti ný risastór málheild opnað nýja möguleika í margvíslegum málfræðirannsóknum og par að auki gagnast í kennslu í málfræði og máltækni.

\subsection{Málheild fyrir málfræðirannsóknir}

Tilkoma rafrænna texta í miklu magni hefur gerbreytt aðstöðu málfræðinga til margs konar málrannsókna. Hægt er að leita að dæmum í gífurlegu textamagni á örskotsstund, eitthvað sem hefði tekið ár eða áratugi að leita í með hefðbundnum lestri. Með pessum hætti má til að mynda skoða breytileika í setningagerð, breytileika og nýjungar í beygingum, orðmyndun og orðaforða, merkingarbreytingar og svo má áfram telja. Par að auki er auðveldara að leita í fjölbreyttari textum en fyrr, ekki bara formlegum yfirlesnum textum eftir pjálfaða höfunda, heldur líka óyfirlesnum textum á óformlegu málsniði eftir allan almenning. Tæknin býður pannig líka upp á möguleika til að skoða breytileika milli mismunandi textategunda og málsniða, breytingar sem eru yfirstandandi og breytileika eftir aldri og uppruna höfunda.

Málfræðingar hafa gert nokkuð af pví að safna dæmum á vefnum með venjulegum leitarvélum. Раð getur gagnast vel, en pótt textamagnið sem pannig er leitað í sé gífurlegt er pað ýmsum annmörkum háð. Рað er til dæmis útilokað að flokka niðurstöðurnar. Pað er ekki hægt að skoða mismunandi málnotkun eftir textategundum, eftir aldri texta eða eftir uppruna, kyni og aldri höfunda. Auk pess er vefurinn síkvikur og leitarvélar mismunandi - niðurstöður geta verið misjafnar frá degi til dags vegna pess að ekki er verið að leita í sömu textum eða með sömu leitarvél. Рað getur pví verið erfitt að prófa niðurstöður með pví að endurtaka tilraunir. Eðli vefsins gerir slíkt ókleift. Pess vegna pótti mikilvægt að koma upp gagnagrunni sem 
hefur pann kost vefsins að geyma gífurlegt og fjölbreytt textamagn en er laus við pá ókosti sem að framan eru taldir.

\subsection{Málheild fyrir máltækni}

Risastórt rafrænt textasafn er grunnforsenda pess að hægt sé að smíða ýmis máltækniverkfæri með peim aðferðum sem skilað hafa bestum árangri síðastliðin ár. Textasafnið er pá notað til að smíða mállíkön sem geta sagt til um tíðni stafa og stafasambanda, tíðni einstakra orða, orðasambanda og heilla setninga. Í talgreiningu eru mállíkön nauðsynleg til að hægt sé að meta líkindi á pví að tilteknar hljóðbylgjur standi fyrir tiltekið orð eða orðastreng. Sams konar mállíkön eru nýtt við gerð talgervla. Tíðniupplýsingar sem fást úr stórum textasöfnum eru nauðsynlegar til að hægt sé að velja rétta framburðinn par sem ritmyndin gefur ekki ótvíræðar vísbendingar. Mállíkön af pessu tagi eru einnig mikilvæg við rannsókna- og próunarstarf á sviði vélrænnar málfræði- og setningagreiningar en með tölfræðilegri greiningu á miklu textamagni er hægt að velja með meira öryggi en ella milli mismunandi greiningarmöguleika. Greining af pessu tagi hefur sjálfstætt fræðilegt gildi, en nýtist síðan í ýmsum hagnýtum verkefnum, t.d. gerð leiðréttingarhugbúnaðar og við próun pýðingarvéla.

\subsection{Málheild fyrir menntun}

Risastórt stafrænt textasafn gefur stúdentum í málfræði tækifæri til að kynnast megindlegum rannsóknum á ýmsum sviðum málfræðinnar. Við notkun pess fá peir pjálfun í tölfræðilegri úrvinnslu á niðurstöðum úr skipulegri leit og textagreiningu en pað gerir peim einnig kleift að gera margvíslegar sjálfstæðar rannsóknir sem peir hefðu ekki haft möguleika á að gera ella. Рað er líka mjög mikilvægt fyrir nemendur í máltækni, eða nemendur í tölvunarfræði sem vinna með textagögn, að hafa hentug íslensk gögn til að pjálfa sig á, t.d. til að vinna upplýsingar úr peim eða greina á ýmsan hátt.

\section{Gagnasöfnun og vinnsla}

Vinna við verkefnið hófst haustið 2015 eftir að hafa fengið 4.950 
púsund króna styrk úr Innviðasjóði og 1.650 púsund króna styrk úr Mótframlagasjóði Háskóla Íslands. Sigrún Helgadóttir og Steinpór Steingrímsson, verkefnastjórar hjá Stofnun Árna Magnússonar í íslenskum fræðum skipulögðu vinnuna og unnu að öflun leyfa frá rétthöfum texta. Starkaður Barkarson var ráðinn til að safna textunum saman, greina og búa um pá svo hægt væri að vinna með allt efnið á sambærilegan hátt. Nokkuð vel gekk að safna efni og sumarið 2017 var efnissöfnun í fyrstu útgáfu hér um bil lokið. Pó átti eftir að setja textana upp svo hægt væri að sækja pá á stöðluðu sniði með lýsigögnum, og uppsetning á leitarkerfi fyrir málheildina var skammt á veg komin. Pá um sumarið hlaut verkefnið sérstakan styrk frá menntamálaráðuneytinu, sem veittur var nokkrum verkefnum sem brýnt pótti að komin yrðu vel á veg pegar verkáætlun um máltækni fyrir íslensku yrði hrundið í framkvæmd (Anna Björk Nikulásdóttir o.fl. 2017). Styrkurinn hljóðaði upp á 8 milljónir og fyrir pá peninga var hægt að klára fyrstu útgáfu málheildarinnar og komast langt með undirbúning annarrar útgáfu. Starkaður hélt áfram að ganga frá textunum og við hlið hans var ráðinn Gunnar Thor Örnólfsson, sem hafði veg og vanda af uppsetningu Korp-málheildarkerfisins (Borin o.fl. 2012) og aðlögun pess að íslensku. Pá var einnig settur upp n-stæðuskoðari sem sýnir breytingar á notkun orða og orðasambanda yfir tíma.

Pegar vinnu við fyrstu útgáfu málheildarinnar lauk höfðu safnast talsvert fleiri textar en lagt var upp með í upphafi. Hún var yfir 1200 milljón orð og par með um 50 sinnum stærri en Mörkuð íslensk málheild. Í pví sambandi er pó rétt að taka fram að MíM er jafnvæg málheild, p.e. reynt var að gæta pess að jafnvægi væri á stærð textaflokka. Engar tilraunir voru gerðar til pess í Risamálheildinni, par er reynt að viða að sér öllu pví sem er aðgengilegt. Notendur málheildarinnar geta svo sjálfir valið pá textaflokka sem peir vilja skoða sérstaklega.

Í fyrstu útgáfu málheildarinnar skiptum við textunum upp í 10 flokka, sbr. Töflu 1, en nánari upplýsingar um hvern textaflokk er að finna á vef Risamálheildarinnar, málheildir.árnastofnun.is. 


\begin{tabular}{|l|r|r|l|}
\hline Textaflokkur & Fjöldi lesmálsorða & Hlutfall & Tímabil \\
\hline Fréttamiðlar & 795.905 .613 & $63,2 \%$ & $1998-2017$ \\
\hline Pingræður & 210.490 .367 & $16,7 \%$ & $1911-2017$ \\
\hline Dómar & 92.702 .603 & $7,4 \%$ & $1999-2017$ \\
\hline Útvarps-/sjónvarpsfréttir & 54.002 .794 & $4,3 \%$ & $2004-2017$ \\
\hline Ípróttavefir & 47.071 .733 & $3,7 \%$ & $2002-2017$ \\
\hline Lög og reglugerðir & 27.079 .422 & $2,2 \%$ & $1275-2017$ \\
\hline Blogg/pistlar & 11.822 .688 & $0,9 \%$ & $1973-2017$ \\
\hline Fræðsluefni fyrir almenning & 10.792 .370 & $0,9 \%$ & $2000-2017$ \\
\hline Útgefnar bækur & 5.247 .476 & $0,4 \%$ & $1980-2008$ \\
\hline Lífsstíll & 4.022 .699 & $0,3 \%$ & $2010-2017$ \\
\hline SAMTALS & $\mathbf{1 . 2 5 9 . 1 3 7 . 7 6 5}$ & $\mathbf{1 0 0} \%$ & \\
\hline
\end{tabular}

Tafla 1: Textaflokkar í Risamálheildinni.

\subsection{Leyfismál}

Málheildin er gefin út undir tveimur mismunandi leyfum. Um helmingur efnisins undir CC BY 4.0 leyfi ${ }^{1}$, sem er opið með litlum takmörkunum. Рað efni má nota í allar rannsóknir en ef textar úr pví eru birtir parf að geta uppruna peirra. Hinn helmingur textanna er gefinn út undir sama leyfi og MíM. Leyfið er takmarkaðra, pað er aðeins veitt til rannsókna í málfræðilegum rannsóknum og í máltækni, ekki má afhenda priðja aðila textana og útgáfa og birting peirra texta sem gefnir eru út undir pví leyfi er bönnuð. Ástæðan fyrir pessari tvískiptingu er að ekki allir rétthafar voru tilbúnir til að leyfa dreifingu sinna texta með eins opnu leyfi og CC BY 4.0. Par sem reynsla var komin á MíM-leyfið og notkun pess hefur gengið snurðulaust var hægt að fá langflesta til að sampykkja pað.

\subsection{Vinnsla textanna}

Stór hluti textanna var sóttur beint á vefsíður rétthafa textanna en sumt fékkst sent yfir netið eða var sótt og afritað á minnislykla. Par sem hægt er að sækja efnið á vef hafa verið sett upp sjálfvirk forrit sem athuga vefina daglega eða vikulega til að kanna hvort nýtt efni hafi bæst við. Ef svo er pá er nýja efnið sótt sjálfkrafa. Pegar efnið hefur verið sótt fer af stað ferli par sem efnið er hreinsað. Fyrsta skrefið er að vinna úr pví lýsigögn og hreina texta. Svo er textunum

1 https://creativecommons.org/ 
skipt upp í setningar og tóka (orð og greinarmerki) en tilreiðari úr IceNLP-pakkanum er notaður við pað (Hrafn Loftsson og Eiríkur Rögnvaldsson 2007). Pá er hver tóki markaður. Í fyrstu útgáfu var notast við IceStagger (Hrafn Loftsson og Östling 2013) en í annarri útgáfu málheildarinnar er notast við nýjan tauganetsmarkara (Steinpór Steingrímsson og Örvar Kárason 2019). Að lokinni mörkun eru uppflettimyndir orðanna fundnar með forritinu Nefni, sem Jón Friðrik Daðason smíðaði.

Að lokum eru textarnir settir upp til dreifingar á XML-sniði og gerðir aðgengilegir í leitarvél fyrir málheildir og n-stæðuskoðara.

\section{Aðgengi að gögnunum}

Risamálheildina má sækja með öllum lýsigögnum á málföng.is. Sem fyrr segir er hún einnig leitarbær í öflugri málheildarleitarvél á vefnum málheildir.árnastofnun.is en par að auki er hægt að skoða tíðni orða eða orðastæðna yfir tíma í n-stæðuskoðara sem smíðaður var ofan á gögnin í Risamálheildinni. Hann er aðgengilegur á n.árnastofnun.is.

\subsection{Málheildarvefur}

Hægt er að leita í öllum textum málheildarinnar í sérstakri málheildarleitarvél (sjá Mynd 1). Við aðlöguðum sænsku málheildarleitarvélina Korp að íslensku en góð reynsla hefur verið af henni á hinum Norðurlöndunum. Leitarvélina má stilla pannig að einungis er leitað í ákveðnum hlutum málheildarinnar eða í öllum textum hennar í einu. Hægt er að leita að stökum orðmyndum eða uppflettimyndum orða, orðasamböndum eða málfræðilegum formdeildum. Hægt er að skoða hvenær tiltekin orð eða málfræðilegar formdeildir standa saman, eða í nágrenni hvort við annað, en einnig er hægt að takmarka leitina við lýsigögnin (t.d. takmarka leit við ártöl eða tímabil, höfunda eða jafnvel pingræður tilgreindra pingmanna). Vefurinn pýðir fyrirspurnir notenda yfir á CQP-fyrirspurnarmálið, sem er sérhannað fyrir málheildir, en gagnagrunnurinn sem geymir textagögnin sjálf skilur aðeins pað fyrirspurnarmál. Notendur geta líka skrifað fyrirspurnir sínar beint á CQP-fyrirspurnarmálinu, sem er nokkuð aðgengilegt peim sem reynslu hafa af forritun eða vinnu við gagnagrunna, en aðrir ættu einnig að geta lært grunnatriðin með aðstoð notkunarleiðbeininga sem aðgengilegar eru á síðunni. 


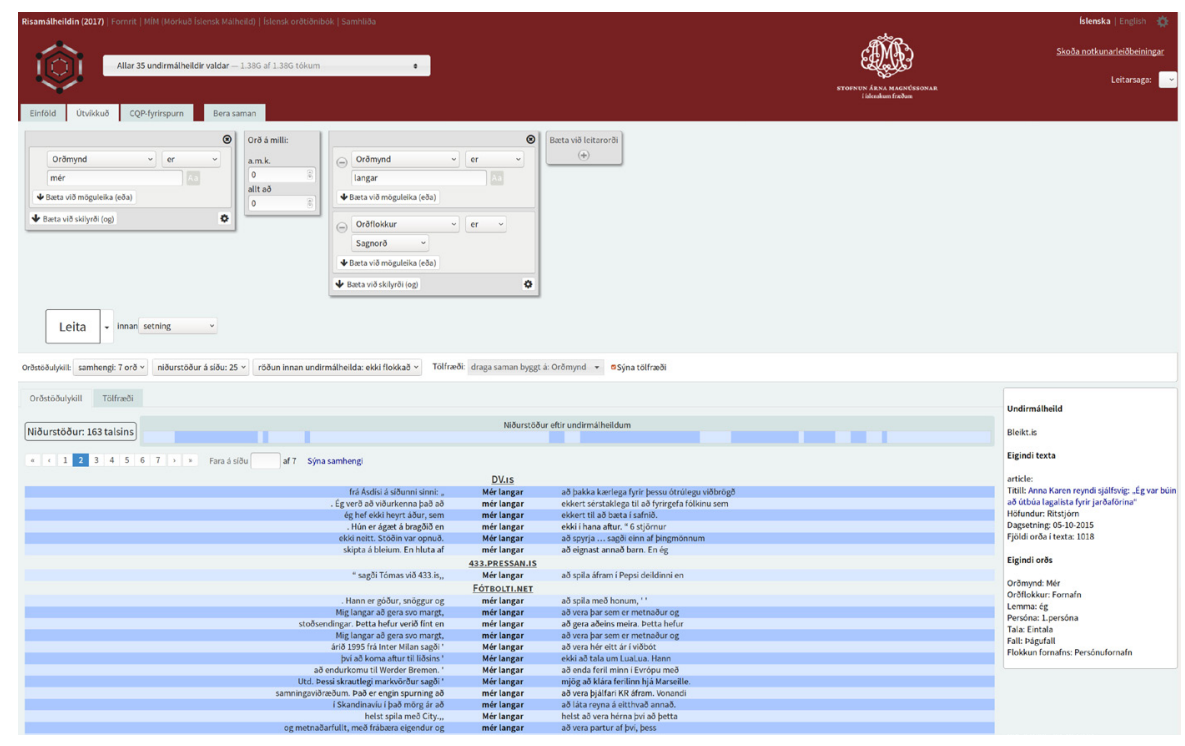

Mynd 1: Skjáskot af málheildarvefnum á málheildir.árnastofnun.is.

Niðurstöður leitar má skoða á vefnum sjálfum eða skrifa pær út í töflur sem hægt er að vinna með í töflureiknum eða með eigin forritum. Pá er einnig hægt að kalla eftir niðurstöðum á JSON-sniði sem getur gagnast peim sem vilja nota annan hugbúnað til að kalla fram niðurstöður úr málheildinni. Vefurinn býður einnig upp á að skoða tölfræðilegar upplýsingar um niðurstöðurnar, til dæmis hlutfallstíðni orðmynda eða í hvaða hlutum málheildarinnar pær er helst að finna.

\subsection{N-stæðuskoðari}

Á málheildarvefnum er hægt að sjá tíðni leitarniðurstaðna yfir tíma. Sú virkni getur verið mjög gagnleg ef verið er að skoða flókna málfræðilega eiginleika en hún er hægvirk og erfitt getur verið að bera saman mismunandi niðurstöður. Ef ætlunin er hins vegar að skoða stök orð eða orðmyndir, eða orðastæður með tveimur eða premur orðum og bera saman við önnur orð eða orðastæður, pá er hægt að gera pað í n-stæðuskoðara sem byggður er ofan á gögnin í Risamálheildinni. N-stæðuskoðari er tæki til að skoða tíðni orða og orðasambanda yfir tíma, en fyrirmyndin er Google Ngram Viewer sem gefur möguleika á að skoða hvernig orðnotkun í ensku og nokkrum öðrum tungumálum breytist yfir tíma. Við uppsetningu 
n-stæðuskoðara Risamálheildarinnar byggðum við á NB N-Gram frá Nationalbiblioteket, Landsbókasafninu í Noregi (Birkenes o.fl. 2015). Textamagn er mjög breytilegt á milli tímabila og niðurstöður n-stæðuskoðarans eru pví kvarðaðar og gefnar sem hlutfall af heildarfjölda orða á hverju ári. Upplýsingar sem svona tól veitir getur veitt innsýn í margvíslega pætti í notkun tungumálsins, t.d. notkun orðasambanda eða hvernig tiltekin orð taka við af öðrum, en pað getur varpað ljósi á tísku, tæknisögu og samfélagsumræðu, svo eitthvað sé nefnt. N-stæðuskoðarinn er aðgengilegur á n.árnastofnun.is (sjá Mynd 2).

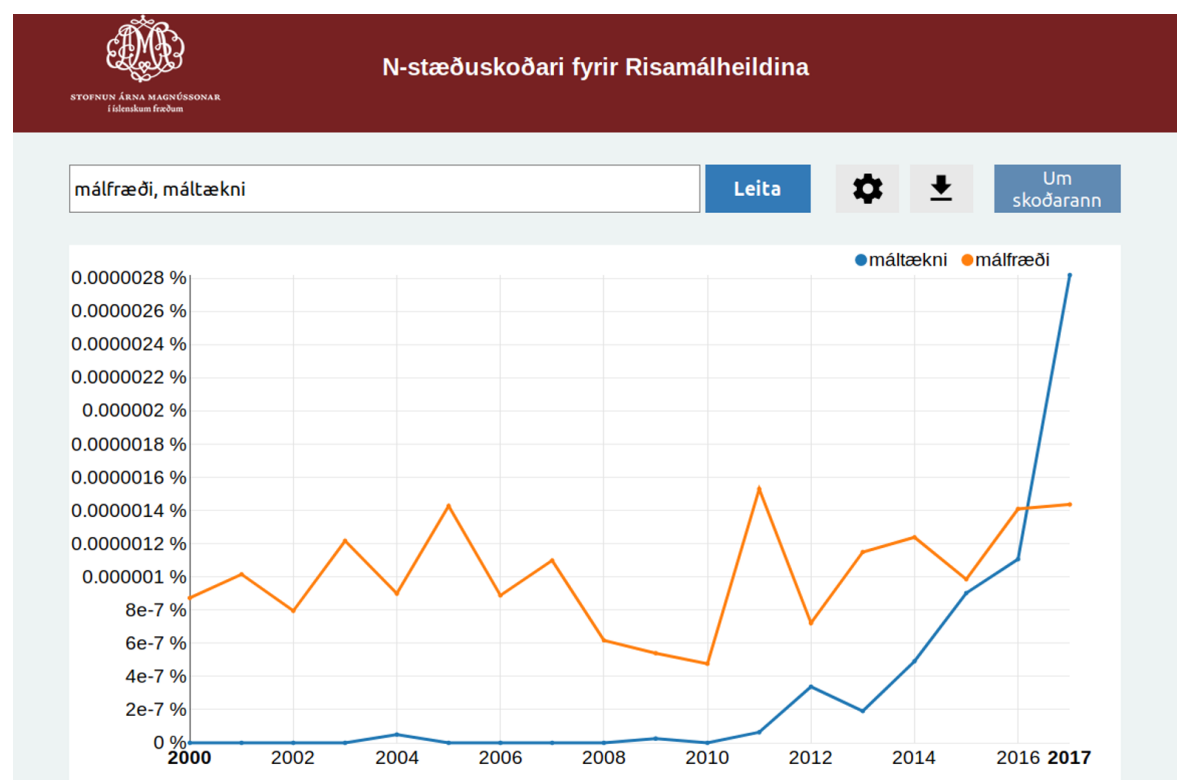

Mynd 2: Skjáskot af n-stæðuskoðaranum á n.árnastofnun.is.

\subsection{Gagnasnið}

Auk pess að vinna með gögnin í peim veflægu verkfærum sem fyrr er getið geta notendur sótt gögnin og unnið með pau sjálfir eins og peim best hentar. Hægt er að sækja gögnin á málföng.is en par er peim dreift í tveimur stórum pökkum, einum fyrir hvora leyfistegund. Í pökkunum eru textarnir á XML-sniði sem byggir á TEI P5 staðlinum (sjá TEI P5: Guidelines 2017). Í XML-skjölunum eru lýsigögn par sem ítarleg grein er gerð fyrir innihaldi hvers skjals. Textunum sjálfum er skipt upp í setningar, par sem pví er við komið, og í hverri setningu eru orðmyndir eins og pær birtast í textanum, ásamt málfræðilegum greiningarstrengjum og lemmum eða uppflettimyndum. 


\section{Að lokum}

Á vef málheildarinnar, málheildir.árnastofnun.is, hefur einnig verið veittur leitaraðgangur að eldri íslenskum málheildum, MíM, fornritamálheild og Íslenskri orðtíðnibók. Reiknað er með pví að nota pessa leitarvél fyrir aðrar íslenskar málheildir sem kunna að verða til á næstu árum. Haldið verður áfram að safna textum og vinna að nýjum útgáfum Risamálheildarinnar á hverju ári, að minnsta kosti á meðan máltækniáætlun fyrir íslensku stendur yfir, en árið 2019 hefst vinna skv. verkáætlun um máltækni fyrir íslensku 2018-2022 (Anna Björk Nikulásdóttir o.fl. 2017). Meðfram pví verður unnið að pví að bæta greininguna og verkfærin sem notendur geta notað til að vinna með málheildargögnin. Pá verður einnig reynt að gæta að pví að leiðbeiningar og upplýsingar um málheildina og verkfærin séu uppfærðar, par sem peirra pykir pörf.

\section{Heimildaskrá}

Anna Björk Nikulásdóttir, Jón Guðnason og Steinpór Steingrímsson. 2017. Máltækni fyrir íslensku 2018-2022: verkáxtlun. Reykjavík: Mennta- og menningarmálaráðuneytið.

Birkenes, Magnus B., Lars G. Johnsen, Arne M. Lindstad og Johanne Ostad. 2015. From digital library to n-grams: NB N-gram. Í: Proceedings of the 20th Nordic Conference of Computational Linguistics (NODALIDA-2015), NEALT Proceedings Series Vol. 23, bls. 293-295. Vilníus.

Borin, Lars, Markus Forsberg og Johan Roxendal. 2012. Korp - the corpus infrastructure of Språkbanken. Í: Proceedings of the Eight International Conference on Language Resources and Evaluation (LREC 2012), bls. 474-478. Istanbúl.

Hrafn Loftsson og Eiríkur Rögnvaldsson. 2007. IceNLP: A Natural Language Processing Toolkit for Icelandic. Í: Proceedings of Interspeech 2007, bls. 1533-1536. Antwerpen.

Hrafn Loftsson og Robert Östling. 2013. Tagging a Morphologically Complex Language Using an Averaged Perceptron Tagger: The Case of Icelandic. Í: Stephan Oepen, Kristin Hagen og Janne Bondi Johannessen (ritstj.). Proceedings of the 19th Nordic Conference of Computational Linguistics (NoDaLiDa -2013), NEALT Proceeding Series 16, bls. 105-120. Oslo.

Sigrún Helgadóttir, Ásta Svavarsdóttir, Eiríkur Rögnvaldsson, Kristín Bjarnadóttir og Hrafn Loftsson. 2012. The Tagged Icelandic Corpus (MIM). Í: Proceedings of the SaLTMiL-AfLaT Workshop on "Language Technology for Normalisation of Less-Resourced Languages", bls. 67-72. Istanbúl.

Steinpór Steingrímsson og Örvar Kárason. Handrit. Augmenting a BiLSTM 
tagger with a Morphological Lexicon and a Seminal Lexical Category Identification Step.

TEI P5: Guidelines. 3.2.0. Síðast uppfært 10. júlí 2017. https://tei-c.org/ guidelines/p5/ (apríl 2019).

\section{Lykilorð}

málheild, íslenska, mörkun, lemmun

\section{Keywords}

corpora, Icelandic, part-of-speech tagging, lemmatization

Steinpór Steingrimsson

Stofnun Árna Magnússonar i íslenskum fræðum

Laugavegi 13

IS-101 Reykjavík

steinthor.steingrimsson@arnastofnun.is 